\title{
Reading Needs Analysis of EFL Learners in the Saudi Context: Identifying Needs and Deficiencies
}

\author{
Asmaa A. AlGhamdi \\ English Language Institute, King Abdulaziz University \\ Kingdom of Saudi Arabia, Jeddah \\ E-mail: aalghamdi2855@stu.kau.edu.sa \\ Sundus Z. AlKadi (Corresponding author) \\ English Language Institute, King Abdulaziz University \\ Kingdom of Saudi Arabia, Jeddah \\ E-mail: sundus.ziad@gmail.com \\ Jumana M. AlHammad \\ English Language Institute, King Abdulaziz University \\ Kingdom of Saudi Arabia, Jeddah \\ E-mail: jomana1990@gmail.com \\ Nadia A. Shukri \\ English Language Institute, King Abdulaziz University \\ Kingdom of Saudi Arabia, Jeddah \\ E-mail: ndshukri@gmail.com
}

Received: October 21, 2018 Accepted: November 3, 2018 Published: November 5, 2018

doi:10.5296/ijele.v6i2.13863 URL: https://doi.org/10.5296/ijele.v6i2.13863

\begin{abstract}
The aim of the current study is to do a reading needs analysis of preparatory-year students in the Saudi context. The scope is to identify the reading needs and deficiencies of EFL learners
\end{abstract}


at King Abdulaziz University. The instrument used is a paper-based questionnaire that was distributed among the participants. A total of sixty-three female students participated in the study. The questionnaire is adapted from the needs analysis questionnaire for non-English learners (Gravatt, Richards \& Lewis, 1997). Two open-ended questions were added in order to get in-depth data from the participants. The statistical analysis was utilized for the quantitative data via SPSS whereas the open-ended questions were analyzed thematically using NVivo. The results demonstrate that EFL learners in the Saudi context have deficiencies of some reading strategies such as reading speed and reading to respond critically. However, they do not have difficulties with general comprehension of reading texts and they are able to read slowly in order to understand the details of the text. Regarding preferences, they mostly like to read works of fiction such as stories or novels but they do not prefer to read long texts. Based on the findings, this study was able to draw a number of implications and propose several recommendations.

Keywords: reading, needs analysis, deficiencies, needs, Saudi, EFL learners

\section{Introduction}

Needs analysis is the collection of data to better understand the needs and deficiencies of language learners, and is particularly useful for learners of English as a Foreign Language (EFL) and experts of Teaching English as a Second Language (TESOL). Needs analysis therefore forms an integral part of modern language course design. In general, needs analysis prioritizes the development of methods that assist tutors and instructors in developing course delivery techniques that put students' needs at the core of their teaching. It thus emphasizes learners' motivation and success as more learners are assigned tasks that meet their learning needs. "Needs analysis is very crucial in language teaching, and it gains support from the new trends that focus on its importance. Students needs can be identified either directly by asking them to put their aims, preferences, priorities, or by using a questionnaire that is used to know their needs" (Habib, 2018). Overall, a number of educational trends come under the umbrella of needs analysis, including models to help teachers develop course delivery methods according to students' needs. The theoretical basis for needs' analysis aims at serving learners' motivation and enhance their success, and self-selection of tasks or learning activities (Graves, 1996; Fatihi, 2003; Weddel \& Van Duzer, 1997).

In particular, needs analysis can be used to gain a better understanding of the reading strategies, habits and comprehension skills of learners, and it is often the first step in curriculum development (Malika, 2017). Comprehension is a particular focus of needs analysis, since without comprehension, reading is considered null and void-a waste. Previous research studies have recommended the application of schema theory before, during, and after reading to activate learners' background knowledge on any subject matter. This enhances learning and can serve as a complementary technique to needs analysis.

Learning strategies that incorporate needs analysis are more learner-centric and pay more attention to the needs of the learner, thereby, achieving better learning outcomes. The 
importance of needs analysis is being realized gradually with the aim of helping curriculum developers and stakeholders understand English-language learners' needs and deficiencies in order to achieve better learning outcomes.

\section{Literature Review}

\subsection{The Importance of Needs Analysis}

Needs analysis is somewhat an unexplored field of research in Saudi Arabia despite its importance. One of the most powerful books that emphasizes the importance of needs analysis when designing courses is "Teachers as Course Developers" by Kathleen Graves. She (1996) provides models and frameworks about successful curricula, as she mentions in Framework components that needs assessment is about two major questions: "What are my learners' needs?" and "How can I assess them so that I can address them?" (p. 13). A review in 1980 found that we conceptualize needs by distinguishing between subjective needs and objective needs (as cited in Graves, 1996, p. 13). Needs analysis is a continual process; as it is ongoing before, within, and after the course period (Graves, 1996, p. 16).

The aim of the current study is to discover reading strategies, the needs and the weaknesses of adult EFL learners of preparatory-year students, so, the importance of needs analysis should be discussed to allow teachers to make informed decisions about the syllabus objectives and aims. A theoretical study in an international context on ESL learners reveals the importance of conducting needs analysis (Weddel, Kathleen Santopietro; Van Duzer, Carol, 1997, p. 1). Another study conducted in India emphasizes the role of needs analysis in ESL program design based on theoretical implications examine the students' needs (Fatihi, 2003, p. 57). The findings from the two surveys confirm that when curriculum content, materials, and instructional methodologies match students' needs, students' motivation and level of success are amplified despite the conflict between students' needs and teacher pedagogy (Weddel \& Van Duzer, 1997; Fatihi, 2003).

In addition, according to other interesting findings of studies in the United States, students' needs are: creating awareness of triangulation through different perspectives whether from students, teachers, and administrative personnel and to have a clear picture of academic needs analysis (Long, 2005; Zhu \& Jeffra, 2005). Boakye and Mbong (2016) present their needs analysis study on first-year sociology students in South Africa which reveals that comprehension is a real challenge due to new vocabulary items and length of texts (p. 235).

\subsection{Reading Comprehension Processes}

Reading is useless without comprehension. In fact, the comprehension process needs a certain input (text) to build vocabulary and interact with the meaning conveyed in the text. Many significant studies indicate the relationship between reading comprehension and second language development. A study conducted in a Canadian university on 37 adult learners in a comprehension-based class and 18 in the four-skill comparison class reveals that the comprehension- based class made gains in discourse knowledge, while the four-skill class 
made gains on content words, and that comprehension-based programs developed learners' proficiency (Paribakht, T. Sima; Wesche, Marjorie Bingham, 1993, pp. 13-23). It is important to keep in mind that schemata are interrelated to reading comprehension, because background knowledge aids comprehending and input. It is vital to inspire ESL readers to follow a reading strategy and activating schemata to become better readers (Stott, 2001, p. 4). Furthermore, a study on English learners in the United States provides advice to practitioners and TESOL researchers about how students learn to read in English in order to decide on the best types of activities, e.g. bottom-up models, top-down models, and interactive models (Burt, Miriam; Peyton, Joy Kreeft; Adams, Rebecca, 2003, pp. 5, 24). Additionally, another study on English learners in Riyadh, Saudi Arabia discusses cognitive tasks involved in reading that teachers use in their instruction, and the findings support the importance of the fluency stage of reading and word recognition (Alyousef, 2006, pp. 64, 70). A survey-based study on 420 ESL certified teachers in New York highlights scaffolding, and reveals that higher level questioning, graphic organizers, informal assessment, underlining, and pre-reading activities enhances reading comprehension (White, 2016, pp. 79-83)

\subsection{Reading Strategies}

Teachers apply reading strategies with their learners, but are learners aware of those strategies? To answer this question, it should be known that reading strategies are cognitive and metacognitive; the cognitive reading strategies is the implicit application of these strategies, whereas the metacognitive reading strategies are the knowledge of how reading strategies are applied. Most studies demonstrate strategic reading in second language learning as a very effective element for ESL learners (Phakiti, 2006; Mikulecky, 2008; Alsamadani, 2008; Iwai, 2009; Vaiciuniene \& Uzpaliene, 2013; Dahish, 2017). A study was conducted in 2008 to explore Saudi students' use of reading strategies in four major universities in Saudi Arabia including King Abdul-Aziz University, King Faisal University, Teachers' College in Jeddah, and Teachers' College in Al-Ahsa. It shows that most Saudi learners are aware of reading strategies, but there is no significant relationship between reading strategies and the level of comprehension as they use questioning strategies, and translation (Alsamadani, 2008, pp. 112-114). In addition, an exploratory study of cognitive reading strategies employed on ESL students of various academic levels in a university in Mississippi, USA was conducted to explore the importance of metacognitive awareness in reading. It indicates the fact that less-advanced readers may require more explicit use of reading strategies (more metacognition) than advanced learners (Iwai, 2009, p. 151). However, online reading strategies employed by university students in a university in Lithuania, demonstrates that online readers work successfully with text to cope with difficulties. Another study in the USA acknowledges that students prefer short stories and "dislike texts stuffed with unfamiliar words"; they are well aware of using metacognitive strategies but they are not consistent in using them (Vaiciuniene \& Uzpaliene, 2013; Dahish, 2017).

\subsection{Difficulties in Reading}

One of the aims of the current study is to explore the deficiencies of reading strategies among Saudi preparatory-year students. One of the studies in Saudi Arabia provides literature about 
how and why Saudi students fail to interact with English reading; as they differ in vocabulary building and reading speed (Alhoshan, 2014, pp. 17, 170). Lempke (2016) appears to explore attitudes of Saudi students in ESL classrooms and their academic reading. She finds that reading in L1 affects L2, and that Saudi students tend to use reading strategies to aid their reading. However, they face difficulty with vocabulary and thus, become demotivated (Alhoshan, 2014; Lempke, 2016).

Further research studies on needs analysis are urgently needed in order to investigate Saudi ESL learners' needs and deficit in reading strategies. The current study might proceed in recognizing the current situation of Saudi preparatory-year students, assist teachers to develop their instructional methods, and try to persuade stakeholders to develop academic English program curricula which fit the current needs of those students. To the best knowledge of the researchers, there are not enough studies on needs analysis in the Saudi context, and therefore, the current study will add a lot to TESOL researchers' ideas on the needs analysis issue that focuses on reading strategies. The major contributions of previous studies assist in creating awareness of the importance of needs analysis, exploring reading comprehension and discovering TESOL methodologies, cognitive and metacognitive strategic reading, and recent difficulties derived from ESL readers.

There are many gaps found in the previous studies which cannot be generalized. The list includes the inadequacy of reading models to teach reading, inactivated schemata of some ESL learners while reading, incomplete picture of needs, limitations either on teachers' perspectives of learners' perspectives (not both), strategies that are not enough to enhance comprehension, and the limited number of participants (Alhoshan, 2014; Alsamadani, 2008; Alyousef, 2006; Boakye \& Mai, 2016; Dahish, 2017; Fatihi, 2003; Gravatt \& Richards, 1997; Graves, 1996; Iwai, 2009; Jalilehvand, 2012; Lempke, 2016; Long, 2005). Further studies have to include more EFL learners in Saudi Arabia, and needs analysis has to be an ongoing process with extended time frames. Thus, conducting a research on reading needs analysis in the Saudi context will add to the existing literature, and will help to identify needs and deficiencies, on one hand, and define updated goals and aims of English programs, on the other. Therefore, the current study aims to address EFL learners' needs and deficiencies of reading strategies in the preparatory-year level at King Abdulaziz University.

\section{The Rationale for the Study}

Needs analysis of L2 reading is an extraordinary and compulsory element when course experts design language programs. There is actually a growing demand for needs analysis to enhance language curricula. Actually, very little attention is paid to needs analysis, so we have to connect theory to practice and rethink about the importance of needs analysis (Long, 2005 , p. 2). In a Saudi context, particularly, in the preparatory-year programs of universities, female students face difficulties in the reading comprehension part of the mid-term and final CBT examinations.

As a result, we investigate "needs analysis" for "reading strategies" and focus on "needs" and "deficiencies" of the targeted students to encourage the curriculum development team and the stake holders to work for a better program which suits students' needs. The central theme of 
this review is the investigation of EFL preparatory year students' awareness of reading strategies, or the deficiency thereof, and their needs in future reading comprehension learning skills. For the organizational pattern of this review, we cover various significant concepts which are complementary to "needs analysis of reading", i.e. needs analysis procedures (NA), comprehension of text, reading strategies (cognitive and metacognitive), and difficulties in reading.

Needs analysis is the process of data collection conducted for the sake of satisfying language learners' necessities, deficiencies, and needs (Nation, I. S. P.; Macalister, John, 2010, p. 26). In this review, we highlight learners' needs and deficiencies. The rationale behind the current study is to make sure that the reading strategies adopted in the English courses for preparatory year students in King Abdul-Aziz University will be relevant and satisfying to them so that EFL teachers can act as TESOL role models to develop textual contents in the required books and modify their teaching strategies and materials.

The overall trends that come under the umbrella of needs analysis are models to assist teachers to develop and deliver courses according to students' needs, to review theoretical implications to emphasize the importance of needs' analysis to serve learners' motivation and enhance success, and to liberate students to select their tasks or activities (Graves, 1996; Fatihi 2003; Weddel \& Van Duzer, 1997). Moreover, comprehension is one of the most important components of reading; as without it, reading is useless and input is disregarded. Many studies reveal concerns about comprehending reading texts through considering language learning outcomes of teaching methodologies to emphasize global comprehension of written and oral texts, schema theory applications to activate learners' background knowledge before, while, and after reading (Paribakht \& Bingham, 1993; Scott, 2001).

Consequently, studies on how adult English learners learn to read English as an L2 demonstrate to practitioners how to decide on required activities and tasks to polish the reading process (Burt, Miriam; Peyton, Joy Kreeft; Adams, Rebecca, 2003, p. 5). In addition, Alyousef (2006) suggests in his theoretical paper the methods teachers use in teaching reading comprehension and the cognitive tasks teachers use whenever they teach reading comprehension in a Saudi context (p. 64). Other studies have been conducted to reinforce employing both cognitive and metacognitive strategic reading form learners' or teachers' perspectives, and effective instruction in reading (Phakiti, 2006; Mikulecky, 2008; Alsamadani, 2008; Iwai, 2009; Vaiciuniene \& Vilhelmina Uzpaliene, 2013; Dahish, 2017). Therefore, raising teachers' and practitioners' awareness of teaching reading comprehension is of vital importance in all contexts.

\section{Research Questions}

1. How often do EFL learners have difficulties with reading strategies? (Deficiencies)

2. What do EFL learners want or prefer to read? (Needs) 


\section{$\triangle$ Macrothink}

\section{Methodology}

\subsection{Participants}

They are EFL students in the preparatory-year level at King Abdulaziz University. They are sixty-three female students who were randomly selected to participate in the current study. Random sampling is considered a good representative and it helps to eliminate bias as it provides every individual an equal opportunity of being selected (McLeod, 2014; Alvi, 2016). According to the Common European Framework of Reference for Languages (CEFR), the participants are at B1. Their ages range from seventeen to nineteen.

\subsection{Piloting}

Prior to the data collection phase, the questionnaire has been piloted to ensure the clarity and comprehensibility of the items. It was randomly distributed to seven of the intended participants. The items were evaluated as very clear and easy to understand.

The value of Cronbach's Alpha is 0.71 which indicates that the questionnaire has an acceptable reliability. This was utilized via SPSS in order to determine the internal consistency of the items. In terms of validity, the questionnaire was given to two TESOL experts to provide their feedback about it and to ensure the accuracy of the Arabic translation. Accordingly, some amendments had taken place before the questionnaire went live.

\subsection{Research Design}

The current study is questionnaire-based. It is used to identify the reading deficiencies and needs of EFL learners at the preparatory-year level in the Saudi context.

\subsection{Instrumentation}

A paper-based questionnaire was distributed among the participants in April 2018 (See Appendix B). On one hand, the first part aims to identify the reading needs of students. It has an open-ended question and a set of dichotomous questions in which students select between "Yes" or "No". On the other hand, the second part aims at investigating the deficiencies of reading strategies among the participants. It has an open-ended question and a five-point Likert scale, with 1 having "always" and 5 having "never". The students are asked to indicate how often they have difficulty with reading strategies. The questionnaire in the current study is adapted from the needs analysis questionnaire for non-English students utilized at the University of Auckland (Gravatt, Richards \& Lewis, 1997). It has been translated into Arabic to ensure the comprehensibility of the items since all the participants are Arab EFL learners.

\subsection{Procedure}

In order to collect the data, a paper-based questionnaire was distributed randomly among the participants. Sixty-three of them completed the questionnaire thoroughly. With regard to data analysis, quantitative data were analyzed via (SPSS) to find the percentages of all answers. Thematic analysis for the two open-ended questions was utilized using NVivo. Based on the findings of the study, a number of implications and recommendations were drawn. 


\section{I Macrothink}

\section{Analysis and Discussion}

\subsection{Statistical Analysis}

The first part of the questionnaire investigates the reading needs of EFL learners. Table 1 indicates that they mostly prefer to read works of fiction such as novels and stories, selected chapters of books, and photocopied notes with the percentages $(73 \%, 68 \%, 78 \%)$ respectively. However, the participants do not prefer to read newspaper articles, text books, workbooks, and computer-presented reading materials with the percentages of $(73 \%, 68 \%, 84 \%, 64 \%)$ respectively. Such results align with the findings of previous studies that students like reading short stories but they not reading long texts (Vaiciuniene \& Uzpaliene, 2013; Dahish, 2017).

Table 1. Types of material students prefer to read $\underline{\text { Needs) }}$

\begin{tabular}{lll}
\hline & Prefer to read & \\
\cline { 2 - 3 } & Yes $(\%)$ & No $(\%)$ \\
\hline 1. Magazine articles & 48 & 52 \\
\hline 2. Newspaper articles & 27 & 73 \\
\hline 3. Works of fiction & 73 & 27 \\
\hline 4. Text books & 32 & 68 \\
\hline 5. Selected chapters of books & 68 & 32 \\
\hline 6. Photocopied notes & 78 & 22 \\
\hline 7. Workbooks & 16 & 84 \\
\hline 8. Laboratory instructions & 60 & 40 \\
\hline 9. Computer-presented reading materials & 36 & 64 \\
\hline
\end{tabular}

The aim of the second part of the questionnaire is to find out the reading strategies that EFL learners deficiencies. As shown in Table 2, most students have difficulty with reading speed and reading to respond critically with the following percentages $(27 \%, 19 \%)$. However, the results demonstrate that students can generally comprehend texts that received the highest percentage (40\%), followed by their ability to read slowly to understand the details of the passage with the percentage of $(31 \%)$. Generally speaking, EFL students at the preparatory-year level in the Saudi context lack several reading strategies such as reading speed, reading to critique the text, understanding specialist vocabulary in a text, and understanding the main points of reading texts. This finding goes in line with Alhoshan's (2014) and Lempke's (2016) results which state that Saudi students have difficulties with reading speed and vocabulary items. Additionally, Table 2 indicates that students have 
difficulty with guessing unknown words from the text and understanding the text organization but such difficulties are rare. In contrast, they do not have any difficulties with the general comprehension of reading texts and they are able to read slowly and carefully to understand the details of the text.

Table 2. Frequency of difficulty students have with the reading strategies (Deficiencies)

\begin{tabular}{llllll}
\hline & $\begin{array}{l}\text { Always } \\
(\%)\end{array}$ & $\begin{array}{l}\text { Often } \\
(\%)\end{array}$ & $\begin{array}{l}\text { Sometimes } \\
(\%)\end{array}$ & $\begin{array}{l}\text { Rarely } \\
(\%)\end{array}$ & $\begin{array}{l}\text { Never } \\
(\%)\end{array}$ \\
\hline $\begin{array}{l}\text { 10. Understanding the main points of text } \\
13\end{array}$ & 11 & 33 & 30 & 13 \\
\hline $\begin{array}{l}\text { 11. Reading a text quickly in order to } \\
\text { establish a general idea of the content } \\
\text { (skimming) }\end{array}$ & 16 & 14 & 22 & 19 & 29 \\
\hline $\begin{array}{l}\text { 12. Reading a text slowly and carefully in } \\
\text { order to understand the details of the text }\end{array}$ & 18 & 14 & 18 & 19 & 31 \\
\hline $\begin{array}{l}\text { 13. Looking through a text quickly in } \\
\text { order to locate specific information } \\
\text { (scanning) }\end{array}$ & 13 & 18 & 22 & 17 & 30 \\
\hline $\begin{array}{l}\text { 14. Guessing unknown words in a text } \\
\text { 15. Understanding text organization }\end{array}$ & 19 & 18 & 23 & 29 & 11 \\
\hline $\begin{array}{l}\text { 16. Understanding specialist vocabulary } \\
\text { in a text }\end{array}$ & 6 & 27 & 33 & 25 & 9 \\
\hline $\begin{array}{l}\text { 17. Reading speed } \\
\text { 18. Reading in order to respond critically }\end{array}$ & 19 & 16 & 25 & 22 & 18 \\
\hline $\begin{array}{l}\text { 19. Understanding a writer's attitude and } \\
\text { purpose }\end{array}$ & 11 & 11 & 29 & 25 & 24 \\
\hline \begin{tabular}{l} 
20. General comprehension \\
\hline
\end{tabular} & 16 & 11 & 14 & 19 & 40 \\
\hline
\end{tabular}

\subsection{Thematic Analysis for the Open-ended Questions}

The responses indicate students' reading preferences (needs) in table 3. Three broad themes emerged from the responses: reading for pleasure, reading for purpose, and reading for schooling. The majority of participants stated that they prefer to read for pleasure, and these responses could be further divided into two sub-themes: free reading and extensive reading. 
Table 3. Students' preferences of reading

\begin{tabular}{|c|c|c|c|}
\hline Themes & $\begin{array}{l}\text { Sub-theme } \\
\text { s }\end{array}$ & Description & $\%$ \\
\hline \multirow{2}{*}{$\begin{array}{l}1 . \\
\text { Reading } \\
\text { for } \\
\text { pleasure }\end{array}$} & $\begin{array}{l}\text { Free } \\
\text { reading }\end{array}$ & $\begin{array}{l}\text { Students enjoy reading stories and books with } \\
\text { illustrations. }\end{array}$ & 68.6 \\
\hline & $\begin{array}{l}\text { Extensive } \\
\text { reading }\end{array}$ & $\begin{array}{l}\text { Students read extensive material for pleasure } \\
\text { on topics that interest them (novels). }\end{array}$ & 5.7 \\
\hline $\begin{array}{l}2 . \\
\text { Reading } \\
\text { for } \\
\text { purpose }\end{array}$ & -- & $\begin{array}{l}\text { Students tend to read for a specific purpose, } \\
\text { such as a task or project at school. }\end{array}$ & 19 \\
\hline $\begin{array}{l}3 . \\
\text { Reading } \\
\text { for } \\
\text { schooling }\end{array}$ & -- & Students read mainly to study school subjects. & 3.8 \\
\hline $\begin{array}{l}4 . \quad \text { No } \\
\text { interests } \\
\text { in reading }\end{array}$ & -- & Students are not engaged in reading activities. & 2.9 \\
\hline
\end{tabular}

\subsection{Reading for Pleasure}

Learners in different academic institutions are exposed to different reading materials and their preferences are based on their reading comprehension abilities.

\subsubsection{Free Reading}

The most striking result to emerge from the data is that $68.6 \%$ of preparatory-year students read only novels. This suggests that the readers were engaged not in the reading activity itself but in other aspects such as the story events, the illustrations and visual aspects provided. This is consistent with studies conducted in the United States which found that students prefer short stories and dislike texts with many unfamiliar words (Vaiciuniene \& Uzpaliene, 2013; Dahish, 2017). That confirms the association between the two themes referred to previously. Similarly, Jalilehvand (2012) analysed the effects of text length and images on reading comprehension among high school students, and found that images had a larger impact on younger learners and less-skilled readers

\subsubsection{Extensive Reading}

The data also identified that $5.7 \%$ of the participants have a zeal for reading about new things in the world. They are motivated by a need to explore and learn. One such participant stated that "I like knowing what is new through exploring the internet and reading articles online." 
This type of student may like reading content that does not directly improve their school work; However, it is important to focus on helping such students access articles they find interesting in order to encourage them to keep reading. Studies have found that students who read online work successfully with texts to cope with difficulties (Vaiciuniene \& Uzpaliene, 2013; Dahish, 2017). This is therefore an approach that teachers should apply in teaching English to Saudi students.

\subsection{Reading for Specific Purposes}

According to the current study, $19 \%$ of the learners are motivated to conduct extensive research. Such individuals have a higher overall reading comprehension capacity than those who do not like or engage in reading, and they have good reading habits - a requirement for educational success. The exploration of different types of content through research can help students understand new concepts presented to them. Teachers can encourage this type of learners by introducing specific topics that interest them. When students are thus encouraged by their teachers, they end up developing a reading culture, which can further enhance both reading and writing skills. Since this approach is different from the one needed for the previously discussed readers, a needs analysis should be conducted to know which kind of students a teacher is handling.

Studies on how adult English learners discover ways to read English as an L2 reveal to practitioners a way to decide on required activities and tasks to sharpen the reading process (Burt, Kreeft Peyton, \& Adams, 2003).

\subsection{Reading for Schooling}

While analysing the open-ended questions, it was thought that reading for schooling would be a major theme. However, this turned out to be a minor theme among the Saudi students under study- Only about 3.8\% read for schooling purposes.

\subsection{No Interest in Reading}

Some people are not in the habit of reading, and their reading comprehension is limited. They learn more from engaging with images or audio content. Recent literature shows that Saudi students are unable to read interactively reflecting their attitudes towards reading itself (Alhoshan, 2014; Lempke, 2016). Data collected for this study similarly found that $2.9 \%$ of the participants were not interested in reading. They did not know how to read effectively, and they found the recommended materials boring due to the lack of illustrations. One of the participants stated that "I would prefer watching documentary films than reading." Given these results, learners who do not have the capacity and interest to read the available materials should be identified by doing a needs analysis. Teachers can then provide these students with alternative content, such as podcasts or videos. This can be done in any educational institution where teachers create podcasts to make the content more available to students with lower reading comprehension. Also, the availability of other formats is important in order for students to select according to their need.

Table 4 presents students' suggestions for improving reading at the university level 


\section{Macrothink}

(deficiencies). Four major themes emerged from the responses: planning, places, content, and demotivation. The first theme has been categorized into three sub-themes: provide courses for reading strategies, devote time, and raising awareness of the importance of reading.

Table 4. Students' suggestions to improve reading at the university level

\begin{tabular}{|c|c|c|c|}
\hline Themes & $\begin{array}{l}\text { Sub-theme } \\
\mathrm{s}\end{array}$ & Description & $\%$ \\
\hline \multirow{3}{*}{ 1.Planning } & $\begin{array}{l}\text { Provide } \\
\text { courses for } \\
\text { reading } \\
\text { strategies }\end{array}$ & $\begin{array}{l}\text { Students understand what they need help in developing } \\
\text { their reading skills and want courses to fill the knowledge } \\
\text { gap. }\end{array}$ & 42.8 \\
\hline & $\begin{array}{l}\text { Devote } \\
\text { time }\end{array}$ & $\begin{array}{l}\text { Students understand the need to spend more time on } \\
\text { reading activities }\end{array}$ & 11.7 \\
\hline & $\begin{array}{l}\text { Raising } \\
\text { awareness }\end{array}$ & $\begin{array}{l}\text { Students understand that awareness about the importance } \\
\text { of reading is required in university faculty. }\end{array}$ & 10.4 \\
\hline & & & 19.5 \\
\hline 2. Places & -- & Students want appropriate reading facilities & \\
\hline 3. Content & -- & Students want the library to provide more genres of text. & 14.3 \\
\hline $\begin{array}{l}4 . \\
\text { Demotiva- } \\
\text { tion }\end{array}$ & -- & $\begin{array}{l}\text { Some students have negative views about attending } \\
\text { libraries }\end{array}$ & 1.3 \\
\hline
\end{tabular}

\subsection{Planning for Reading}

\subsubsection{Providing Time}

Time management is an essential tool in all educational domains. Everything that is done has been planned for; course lessons are prepared to ensure that all learners and teachers manage their time carefully. Given this, $11.7 \%$ of the students in this study argued that the time allocated to reading should be increased and there should be a well laid out plan for how reading should be done. Usually, libraries within educational facilities close early, which means that students who cannot read and understand things quickly are unable to spend as much time as they need in the library. Expanding hours of university libraries would thus help 
ensure that students with varying reading capabilities are given the opportunity to enhance their reading skills. An initial needs analysis would be necessary to understand how much time learners require for reading.

\subsubsection{Providing Courses about Reading Strategies}

Reading strategies are beneficial for enhancing reading comprehension, which in turn allows readers to make sense of what they are reading. According to the current study, $42.8 \%$ of the participants understood that they need help in developing their reading skills, and specifically requested opportunities to take courses on how to become strategic readers. A recent survey of ESL teachers highlighted the importance of scaffolded learning for students to discover strategic reading tools to build comprehension (White, 2016, pp. 1-92).

\subsection{Improvement of Reading Places}

Environments can affect how comfortable learners are when reading. Research has found a strong relationship between study support and difficulties in using facilities (Phakiti \& Li, 2011). Proper use of study facilities can have a positive effect on the quality of learning and academic achievement outcomes (Berno \& Ward, 2003; Bundy, 2003; Jackson, 2005; Wang, 2006). Learners are attracted to reading environments and places where they can spend long hours for reading. About $19.5 \%$ of the participants indicated a need for more places that are conducive to reading and one of them suggested establishing an ambient library. This could include new library facilities as well as more reading spaces within educational institutions. The creation of additional and more attractive reading environments could therefore help students spend more time on reading and improve their reading skills.

\subsection{Provide a Variety of Content}

The content provided to learners often influences their abilities to understand different concepts. A variety of learning materials should be provided to students based on their different needs and abilities. Regarding this study, $14.3 \%$ of the participants indicated that they would like to be provided with simple content. One of the participants commented that "some of the content that we have access to in the library is too difficult to understand." Also, they would like to be provided with illustrated materials as they believed that illustrated information would enhance their understanding. Therefore, teachers should try to introduce materials that suit students' level. Libraries should also provide illustrated materials and other simple content which can help to enhance learners' comprehension in the long run.

\section{Conclusion}

To sum up, the aim of the study is to do a reading needs analysis of EFL learners in the Saudi context with the focus on identifying the needs and deficiencies. The participants are sixty-three female students. The study is questionnaire-based that is adapted from the needs analysis questionnaire for non-English students (Gravatt, Richards \& Lewis, 1997). The questionnaire has dichotomous questions and another set of questions of five-point Likert scale. Also, it has two open-ended questions. The quantitative data were analyzed via SPSS 
whereas thematic analysis was utilized using NVivo. The findings indicate that Saudi EFL learners lack some reading strategies such as reading speed and reading to critique the text, and they have preferences to read some materials like novels more than others.

\section{Implications and Recommendations}

Based on the findings of the current study, there are some implications and recommendations that need to be mentioned. The results of the study encourage teachers to focus on students' deficiencies and needs in order to improve their reading ability. For example, students need instruction on how to read to critique a particular text and they need to improve their reading speed through extensive practice of timed-reading. In addition, EFL learners' needs should be taken into consideration by integrating their preferences in reading classrooms. The findings indicate that students prefer to read works of fiction such as novels and short stories, so, such preferences need to be addressed. For example, teachers can assign some stories for students to work in groups to perform a role-play, make presentations or summarize the main points. Also, teachers need to implicitly or explicitly teach reading strategies to students and include a variety of reading materials while designing the course syllabus. Students should develop their autonomy by searching and reading based on their interests rather than depending on their teachers or the course materials. It is of paramount importance to do a needs analysis prior to designing any reading course in order to meet students' different needs and preferences.

\section{References}

Alhoshan, B. (2014). Affordances and Constraints in an ESL REading Classroom: A Study of Four Saudi Students' Cases. UMI ProQuest, 1-187. https://doi.org/10.1.1.842.5495

Alsamadani, H. A. (2008). The Relationship between Saudi EFL College-Level Students' Use of Reading strategies and Thier EFL Reading Comprehension. UMI Microform ProQuest, 1-173. Retrieved from https://etd.ohiolink.edu/

Alvi, M. (2016). A Manual for Selecting Sampling Techniques in Research. Retrieved from https://mpra.ub.uni-muenchen.de/70218/

Alyousef, H. S. (2006). Teaching Reading Comprehension to ESL/EFL Learners Journal of Language and Learning. Journal of Language and Learning, 5(1), 63-73.

Boakye, N. A., \& Mai, M. M.-2. (2016). A Needs Analysis for a Discipline-Specific Reading Intervention. Eric, 9(3), 235-247. Retrieved from https://eric.ed.gov/?id=EJ1095543

Burt, Miriam; Peyton, Joy Kreeft; Adams, Rebecca. (2003). Reading and Adult English Language Learners. Washington, DC: Center for Applied Linguistics. Retrieved from https://eric.ed.gov/?id=ED505537 


\section{Macrothink}

Dahish, J. M. (2017). ESL Students' Metacognitive Awareness of Their Reading Strategies. ProQuest, 1-106.

Fatihi, A. R. (2003). The Role of Needs Analysis in ESL Program Design. South Asian Language Review, 13(1-2), 39-59. Retrieved from http://www.geocities.ws/southasianlanguagereview/SecondLanguage/fatihi.pdf

Gravatt, B., Richards, J. \& Lewis, M. (1997). Language Needs in Tertiary studies. Auckland: Occasional Paper Number 10, University of Auckland Institute of Language Teaching and Learning.

Graves, K. (1996). Teachers as Course Developers. New York: Cambridge University Press.

Iwai, Y. (2009). Metacognitive Awareness and Strategy Use in Academic English Reading among Adult English as a Second Language (ESL) Students. UMI Microform ProQuest, 1-212. Retrieved from https://aquila.usm.edu/cgi/

Jalilehvand, M. (2012). The effects of text length and picture on reading comprehension of Iranian EFL students. Asian Social Science, 8(3), 329. Retrieved from http://academia.edu

Lempke, K. (.-1. (2016). . ESL Students from the Arabian Gulf and their Attitudes towards Reading. ProQuest, 1-114. https://doi.org/10250526

Long, M. H. (2005). Second Language Needs Analysis. New York: Cambridge University Press.

McLeod, S. (2014). Sampling Methods. Retrieved from https://www.simplypsychology.org/sampling.html

Mikulecky, B. S. (2008). Teaching Reading in a Second language. Pearson Education, 1-6.

Nation, I. S. P. \& Macalister, John. (2010). Language Curriculum Design. New York: Routledge.

Paribakht, T. Sima \& Wesche, Marjorie Bingham. (1993). Reading Comprehension and Second Language Development in a Comparision-Based ESL Program. TESL CANADA JOURNAL, 11(1), 9-29.

Phakiti, A. (2006). Theoretical and Pedagogical Issues in ESL/EFL Teaching of Strategic Reading. University of Sydney Papers in TESOL, 1, 19-50. Retrieved from researchgate.net

Phakiti, A., \& Li, L. (.-2. (2011). General academic difficulties and reading and writing difficulties among Asian ESL postgraduate students in TESOL at an Australian university. RELC Journal, 42(3), 227-264. Retrieved from journals.sagepub.com

Stott, N. (2001). Helping ESL Students Become Better Readers: Schema Theory Applications and Limitations. The Internet TESL Journal, 7(11), 1-7. Retrieved from http://semanticscholar.org 
Vaiciuniene, V., \& Uzpaliene, D. (2013). Metacognitive Online Reading Strategies in Foriegn Language Learning Context at University. Social Technologies, 3(2), 316-329. Social Technologies, 3(2), 316-329. Retrieved from semanticscholar.org

Weddel, Kathleen Santopietro \& Van Duzer, Carol. (1997). Needs Assessment for Adult ESL Learners. Ericae.net, 1-4. Retrieved from http://ed.gov

White, P. A. (2016). A Qualitative Study of ESL Teacher Experiences and Perceptions of Comprehension and Scaffolding for Refugee Students. ProQuest, 1-92. https://doi.org/10092279

Zhu, W., \& Flaitz, J. (2005). Using Focus Group Methodology to Understand International Students' Academic Language Needs: A Comparison of Perspectives. TESL-EJ, 8(4), 1-9. https://doi.org/1068108

\section{Appendix}

Appendix 1. The English version of the questionnaire adapted from (Gravatt, Richards \& Lewis, 1997)

The following questions concern the reading tasks required of you during the course.

\section{Which of the following types of material you prefer to read:}

\begin{tabular}{|l|l|l|}
\hline \multirow{2}{*}{} & Prefer to read & \multicolumn{2}{l|}{} \\
\cline { 2 - 3 } & Yes & No \\
\hline 1. Magazine articles & & \\
\hline 2. Newspaper articles & & \\
\hline 3. Works of fiction & & \\
\hline 4. Text books & & \\
\hline 5. Selected chapters of books & & \\
\hline 6. photocopied notes & & \\
\hline 7. Workbooks & & \\
\hline 8. Laboratory instructions & & \\
\hline 9. Computer-presented reading materials & & \\
\hline
\end{tabular}


2. What do you prefer to read?

\section{Indicate how often you have difficulty with each of the following:}

\begin{tabular}{|c|c|c|c|c|c|}
\hline & Always & Often & Sometimes & Rarely & Never \\
\hline 10. Understanding the main points of text & & & & & \\
\hline $\begin{array}{l}\text { 11. Reading a text quickly in order to } \\
\text { establish a general idea of the content } \\
\text { (skimming) }\end{array}$ & & & & & \\
\hline $\begin{array}{l}\text { 12. Reading a text slowly and carefully in } \\
\text { order to understand the details of the text }\end{array}$ & & & & & \\
\hline $\begin{array}{l}\text { 13. Looking through a text quickly in } \\
\text { order to locate specific information } \\
\text { (scanning) }\end{array}$ & & & & & \\
\hline 14. Guessing unknown words in a text & & & & & \\
\hline 15. Understanding text organization & & & & & \\
\hline $\begin{array}{l}\text { 16. Understanding specialist vocabulary } \\
\text { in a text }\end{array}$ & & & & & \\
\hline 17. Reading speed & & & & & \\
\hline 18. Reading in order to respond critically & & & & & \\
\hline $\begin{array}{l}\text { 19. Understanding a writer's attitude and } \\
\text { purpose }\end{array}$ & & & & & \\
\hline 20. General comprehension & & & & & \\
\hline
\end{tabular}

4. What are your suggestions to improve reading at the university level? 
Appendix 2. The Arabic version of the questionnaire distributed to the participants

تهوف الأسئلة التالية للاستفسار عن مهام القراعة المطلوبة منتك خلال الفصل الاراسي، فضلًا حددي ما يلي:

1. ما هي أنواع المواد التي تفضلين قراعتها

\begin{tabular}{|c|c|c|}
\hline \multicolumn{2}{|c|}{ تفضلين قر اءتها } & \\
\hline$y$ & 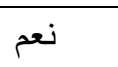 & مقال صحفي في مجلة \\
\hline$y$ & 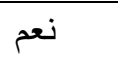 & مقالة في جريدة \\
\hline y & 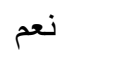 & عمل فني \\
\hline$y$ & 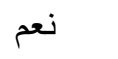 & كتاب در اسي \\
\hline$y$ & 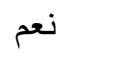 & (chapters)فصول معينة من كتاب ( \\
\hline y & 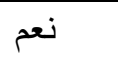 & نوتات مصورة \\
\hline y & 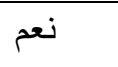 & كتاب التمارين \\
\hline$y$ & 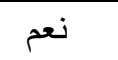 & تعليمات المختبر \\
\hline$y$ & 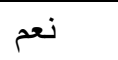 & مو اد للقر اءة على الحاسب الآلي \\
\hline
\end{tabular}

2. ماذا تفضلين أن تقرأين؟ 
3. حددي عدد المرات التي تواجهين فيها صعوبة في كل مما يلي:

\begin{tabular}{|c|c|c|c|c|c|}
\hline لا أو أبداً & أوادراً & أواجه & غأوالجاً & أواجه & \\
\hline 5 & 4 & 3 & 2 & 1 & 1. فهم النقطة الرئيسية من النص \\
\hline 5 & 4 & 3 & 2 & 1 & 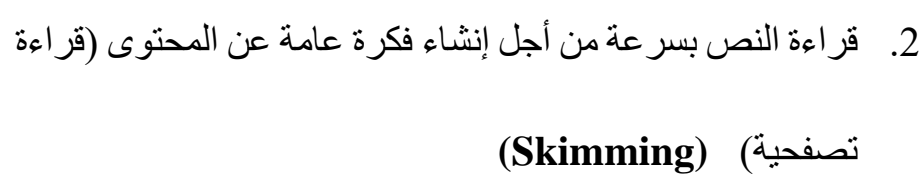 \\
\hline 5 & 4 & 3 & 2 & 1 & 3. قراءة النص بططء وبعناية لفهم تفاصيل النص \\
\hline 5 & 4 & 3 & 2 & 1 & 4. النظر سريعا للنص لإيجاد معلومة محددة (Scanning) \\
\hline 5 & 4 & 3 & 2 & 1 & 5. تخمين الكلمات غير المعروفة في النص \\
\hline 5 & 4 & 3 & 2 & 1 & 6. فهم هيكلة النص (طريقة ترتيبه) \\
\hline 5 & 4 & 3 & 2 & 1 & 7. فهم كلمة محددة في النص \\
\hline 5 & 4 & 3 & 2 & 1 & 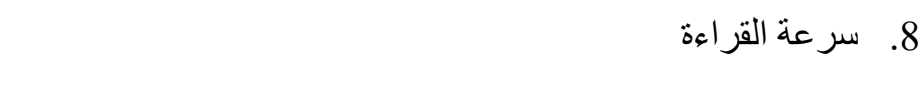 \\
\hline 5 & 4 & 3 & 2 & 1 & 9. القراءة من أجل نقد النص \\
\hline 5 & 4 & 3 & 2 & 1 & فهم فكر الكاتب و الغرض منه \\
\hline 5 & 4 & 3 & 2 & 1 & 10. الفهم العام للنص \\
\hline
\end{tabular}


4. ماهي اقتراحاتك لتحسين القراءة في المستوى الجامعي؟

\section{Copyright Disclaimer}

Copyright for this article is retained by the author(s), with first publication rights granted to the journal.

This is an open-access article distributed under the terms and conditions of the Creative Commons Attribution license (http://creativecommons.org/licenses/by/3.0/). 